\title{
DESIGNING NEW MOTHER TINCTURES FOR INCREASED ANTIOXIDANT EFFICIENCY ON INFLAMMATORY INTESTINAL DISEASES
}

\author{
SORINA NICOLETA VOICU ${ }^{1}$, ANCA HERMENEAN ${ }^{2,3}$, NELI-KINGA OLAH ${ }^{4,5}$, LILIANA \\ BADULESCU $^{6}$, MIRUNA SILVIA STAN ${ }^{1 *}$, ANCA DINISCHIOTU $^{1}$ \\ ${ }^{1}$ Department of Biochemistry and Molecular Biology, Faculty of Biology, University of Bucharest, 91-95 Splaiul Independentei, \\ 050095 Bucharest, Romania \\ ${ }^{2}$ The Institute of Life Sciences, "Vasile Goldiș" Western University of Arad, Arad, Romania \\ ${ }^{3}$ Department of Histology, Faculty of Medicine, "Vasile Goldiș” Western, University of Arad, Arad \\ ${ }^{4}$ SC PlantExtrakt SRL, 407059 Rădaia, Cluj-Napoca, Romania \\ 5 "Vasile Goldiș” Western University of Arad, Faculty of Pharmacy, 86 L. Rebreanu, 310414 Arad, Romania \\ ${ }^{6}$ Department of Bioengineering of Horticulture Systems, University of Agronomic Sciences and Veterinary Medicine, 59 \\ Mărăști Boulevard, 011464 Bucharest, Romania
}

*corresponding author: miruna.stan@bio.unibuc.ro

Manuscript received: October 2018

\begin{abstract}
Four mother tinctures of Filipendula ulmaria, Fraxinus excelsior, Gaultheria procumbens and Populus tremula were characterized from the point of view of the antioxidant effect, and were tested in vitro on colon cell cultures in order to select the most potent extracts for intestinal inflammatory pathologies. The antioxidant capacity of the selected tinctures was determined by measuring 2,2-diphenyl-1-picryl-hydrazyl (DPPH)-radical-scavenging activity, oxygen radical absorbance capacity (ORAC) and nitric oxide radical scavenging activity. Our results showed that all extracts exhibited antioxidant capacity, but the greatest effect was observed for Filipendula ulmaria. In addition, it was revealed that they were not cytotoxic to intestinal Caco-2 cells, our findings providing valuable information for introducing these tinctures on the Romanian market of homeopathic products.
\end{abstract}

\section{Rezumat}

Patru tincturi mamă de Filipendula ulmaria, Fraxinus excelsior, Gaultheria procumbens și Populus tremula au fost caracterizate din punct de vedere al efectului antioxidant și au fost testate in vitro pe culturi celulare de origine intestinală pentru a selecta cele mai eficiente extracte pentru patologiile inflamatorii intestinale. Efectul antioxidant al tincturilor selectate a fost determinat prin măsurarea activităţii de neutralizare a radicalilor de 2, 2-difenil-1-picril-hidrazil (DPPH), a capacității de absorbție a radicalilor de oxigen (ORAC) și a activității de captare a radicalilor de oxid nitric. Rezultatele obținute au arătat că toate extractele prezintă o capacitate antioxidantă, dar efectul cel mai bun a fost observat în cazul extractului de Filipendula ulmaria. În plus, s-a constatat că acestea nu au fost citotoxice pentru celulele Caco-2 intestinale, rezultatele noastre oferind informații valoroase pentru introducerea acestor tincturi pe piaţa produselor homeopatice românești.

Keywords: mother tinctures, antioxidant capacity, in vitro, Filipendula ulmaria, Fraxinus excelsior, Gaultheria procumbens, Populus tremula

\section{Introduction}

Natural antioxidants found in various organs of plants have attracted a growing interest from consumers and the scientific community. Different studies have shown that frequent consumption of fruits, vegetal and other vegetable products is associated with a lower risk of coronary artery disease [17] or cancer [19]. Phytotherapeutic products obtained by different methods whereby bioactive compounds beneficial to human health remain unaltered by enzymatic degradation processes or due to higher temperatures used for drying could be used for the reduction of intestinal inflammation, which is a disease that affects annually over 1 million people in the United States and 2.5 million in Europe [9]. Different plants contain antioxidants capable of neutralizing free radicals (peroxides, hydroperoxides, lipid peroxides, superoxide anions, hydroxyl ions) that are present in biological systems. Their content in alkaloids and phenolic substances, such as: flavonoids, phenolic acids and tannins [6], can be much more potent considering their antioxidant effect than vitamin $\mathrm{C}$ or vitamin $\mathrm{E}$. These antioxidant compounds may have important biological functions such as: anti-inflammatory, anti-carcinogenic, antisclerotic and anti-degenerative [10]. 
Filipendula ulmaria, also known as the meadowsweet or mead wort, is a herbaceous, perennial medicinal plant, whose white flowers are arranged in a mantle. Dried flowers, leaves and rhizomes are used for medicinal purposes as they contain more than 70 phenolic compounds, such as phenolic acids (gallic acid, salicylic acid, etc.), flavonoids, hydrolysable and condensed tannins. Their pharmacological effects include: anti-inflammatory, anti-rheumatic, analgesic, antipyretic, astringent and diuretic effects. In addition, the flowers are used to treat fever, gout and urinary tract infections, and represent an important component of mixed herbal teas used as remedies for influenza, rheumatism or bladder disease [11].

Fraxinus excelsior, known as the ash, is related to the Oleaceae family and spread in temperate areas of the world. The chemical composition of its bark consists of cellulose, hemicellulose, lignin and a negligible amount of tannins [20]. It contains many forms of coumarins (such as fraxin and fraxetin), secoiridoids, phenolic components and flavonoids. Leaf and bark extracts can be used to treat various conditions such as rheumatism, gout, diarrhoea and intestinal parasites. Also, it has been shown that glycoside extracts from fruit and seeds have had a beneficial effect on reducing blood glucose levels without affecting insulin levels.

Gaultheria procumbens (known as checkerberry or American wintergreen) is rich mainly in salicylic acid derivatives, such as methyl salicylate, being used to treat inflammatory disorders (such as rheumatoid arthritis, swelling pain, chronic tracheitis, cold, and prostatitis [14].

The chemical compounds (such as polyphenols, terpenoids, fatty acids, aliphatic alcohols, astringent tannins, gums, resins, waxes, and emollient saponins) of Populus tremula are known to have various biological activities such as fungicide, antioxidants, antitumor, antiseptic and antiviral agents [3]. Our study aimed to achieve a proper characterization of these four mother tinctures (obtained from Filipendula ulmaria, Fraxinus excelsior, Gaultheria procumbens and Populus tremula) from the point of view of the antioxidant effect, and to test their in vitro effect on colon cell cultures in order to select the most potent extracts for intestinal inflammatory pathologies.

\section{Materials and Methods}

Obtaining and characterization of mother tinctures The mother tinctures (MT) used in this study were prepared by SC PlantExtrakt SRL according to German Homeopathic Pharmacopoeia (GHP) and European Pharmacopoeia (EP), the vegetal materials being harvested from Mărișel region, Cluj county, Romania. Filipendula ulmaria MT was obtained from dry roots (collected in April 2014) using as solvent $70 \%$ vol. ethanol. Fraxinus excelsior MT was prepared from fresh bark (harvested in March 2016) using as solvent 90\% vol. ethanol. Gaultheria procumbens MT was prepared from dry leaves (obtained from Alfred Galke GmbH, Germany, the origin of vegetal material being USA) using as solvent $90 \%$ vol. ethanol. One part of ground vegetal material was mixed for 10 days, 10 - 20 minutes/day with 10 parts of solvent (in the case of $F$. ulmaria or G. procumbens) or with 1.4 parts of solvent (for $F$. excelsior or $P$. tremula). The extraction was performed at cold, by maceration. After 10 days the extract was separated and filtrated. Determination of total polyphenols content

The total polyphenol content was measured according to the protocol indicated by Singleton et al. [18]. The polyphenols from the mother tinctures react with the Folin-Ciocâlteu reagent and form a blue complex that will be quantified by a spectophotometric method at $760 \mathrm{~nm}$. The total concentration of polyphenols was determined according to a standard, in this case gallic acid. The content in polyphenols is expressed in grams equivalent to gallic acid. Gallic acid (3, 4, 5-trihydroxybenzoic acid) is used as a standard antioxidant for the spectrophotometric determination of antioxidant activity.

\section{DPPH-Scavenging Activity}

The antioxidant capacity of mother tinctures was determined using the 2,2-diphenyl-1-picrylhydrazyl radical (DPPH) according to the method of Burits and Bucar [5]. Different tincture concentrations were mixed with $0.04 \%$ alcoholic DPPH in a ratio of $1: 100$. The absorbance (A) of sample and blank (where the tincture is substituted by an equal volume of $70 \%$ ethanol) was measured at $517 \mathrm{~nm}$ after a 30-minute incubation in dark at room temperature using a FlexStation 3 Multi-Mode Microplate Reader (Molecular Devices LLC). Radical scavenging capacity (RSC, expressed as a percentage) was calculated using the following formula:

$$
\operatorname{RSC}(\%)=\left[\left(A_{\text {blank }}-A_{\text {sample }}\right) / A_{\text {blanck }}\right] \times 100 .
$$

Oxygen Radical Absorbance Capacity (ORAC) Assay The antioxidant capacity was evaluated by the ORAC assay, following the protocol described by Davalos et al. [7]. A volume of $20 \mu \mathrm{L}$ of tincture or phosphate buffer (for blank) was mixed with $5 \mu \mathrm{L}$ $75 \mathrm{mM}$ phosphate buffer ( $\mathrm{pH}$ 7.4) and $365 \mu \mathrm{L}$ fluorescein $48 \mathrm{nM}$, and incubated for 15 minutes in dark at $37^{\circ} \mathrm{C}$. The peroxyl radical was generated by adding $60 \mu \mathrm{L} \quad 2$, 2'-azobis (2-amidino-propane) dihydrochloride $\mathrm{mM}$ (AAPH), which was freshly prepared before each test. The fluorescence intensity (FL) was read for 30 minutes at intervals of one minute using the FlexStation 3 Multi-Mode Microplate Reader (Molecular Devices LLC) and the wave- 
FARMACIA, 2019, Vol. 67, 2

lengths set at $485 \mathrm{~nm}$ excitation and $520 \mathrm{~nm}$ emission. In parallel, a standard curve was prepared with Trolox (6-hydroxy-2, 5, 7, 8-tetramethylcroman2-carboxylic acid) at concentrations ranging from 0 to $100 \mu \mathrm{M}(0,12.5,25,50,75$ and $100 \mu \mathrm{M})$. The calculation of the results was performed using the following formula: The value of:

\section{ORAC $=($ FLProbe- FLBlank $) /($ FLTrolox-FLBlank $) x$ (Trolox molarity/sample molarity).}

This ORAC value can also be expressed as Trolox equivalents per gram of fresh substance.

Cell culture

The human colorectal adenocarcinoma clone of Caco-2 was obtained from the ATCC (American Type Cell Culture, CCL-2102). Cells were cultured in Dulbecco's Modified Eagle's Medium (DMEM; Gibco) supplemented with heat-inactivated fetal bovine serum (FBS; Gibco, Grand Island, NY, USA) to a final concentration of $10 \%$. The cell line was maintained at $37^{\circ} \mathrm{C}$ in a humidified atmosphere with 5\% $\mathrm{CO}_{2}$. Dulbecco's Modified Eagle Medium (DMEM) containing $4.5 \mathrm{~g} / \mathrm{L}$ glucose supplemented with $10 \%$ foetal bovine serum, $4 \mathrm{mM}$ glutamine, $1 \%$ penicillin/streptomycin antibiotics (PSA) and $1 \%$ non-essential amino acids. The cells were seeded on 24-well plates at a density of $5 \times 10^{4} \mathrm{per}$ well.

\section{Cytotoxicity assay}

The cytotoxic activity was determined using the MTT (3-(4, 5-dimethylthiazol-2-yl)-2,5-diphenyltetrazolium bromide) colorimetric assay [15]. When cells were at $70 \%$ confluence, the culture medium was replaced with complete medium containing concentrations of the different mother tinctures (5, 25,50 and $100 \mu \mathrm{g} / \mathrm{mL}$ ).

After 12, 24 and 48 hours the treated media was removed and MTT solution $(1 \mathrm{mg} / \mathrm{mL})$ was added to each well. Then, the cells were incubated with MTT solution, for two hours at $37^{\circ} \mathrm{C}$. Afterwards the MTT solution was removed and the formazan crystals were dissolved in $250 \mu \mathrm{L}$ isopropanol per well and the optical density was measured at 595 $\mathrm{nm}$, using the FlexStation 3 Multi-Mode Plate Reader Microplate Reader (Molecular Devices LLC). The results were expressed taking into consideration as $100 \%$ viability the value corresponding to the untreated control.

Cell lysate preparation

After treatment, cells were harvested from culture flasks using trypsin-EDTA solution and centrifuged at $1500 \mathrm{rpm}, 4^{\circ} \mathrm{C}$ for $5 \mathrm{~min}$. Then, they were resuspended in $0.2 \mathrm{~mL}$ of phosphate buffered saline (PBS), sonicated (three times for 30 seconds on ice) using Hielscher Ultrasonic processor UP50H and centrifuged at $5000 \mathrm{rpm}, 4^{\circ} \mathrm{C}$ for $10 \mathrm{~min}$. The supernatant was aliquoted and stored at $-80^{\circ} \mathrm{C}$ and used for subsequent biochemical determinations. Protein concentration was measured according to Bradford method [4] using bovine serum albumin (BSA) as standard protein.

\section{MDA (malondialdehyde) level measurement}

Determination of MDA level, one of the markers of lipid peroxidation was assessed using thiobarbituric acid (TBA) as a reactive substance. Malondialdehyde (MDA) was measured according to the method described by Del Rio et al. [8]. MDA-TBA adducts formed following the reaction between the MDA present in the biological sample and the TBA at $37^{\circ} \mathrm{C}$ can be measured fluorimetrically (excitation $\lambda=$ $520 \mathrm{~nm}, \lambda$ emission $=549 \mathrm{~nm}$ ) using a Jasco FP750 spectrofluorometer. The results were expressed as nmoles of $\mathrm{MDA} / \mathrm{mg}$ of cellular protein and MDA concentration was calculated using a calibration curve with 1,1,3,3-tetramethoxy propane concentrations in the range of $0.5-5 \mu \mathrm{M}$.

Statistical analysis

The data were expressed as mean \pm standard deviation (SD) for triplicate readings and statistical analysis was performed using Student's $t$ test (Microsoft Excel). A $p$ value $<0.05$ was considered statistically significant and data were represented as graphics relative to control which was considered $100 \%$.

\section{Results and Discussion}

Antioxidant efficiency of mother tinctures

In this study we used different methods to measure the antioxidant activity of mother tinctures of Filipendula ulmaria, Fraxinus excelsior, Gaultheria procumbens, and Populus tremula.

Table I

Evaluation of antioxidant capacity of mother tinctures of Filipendula ulmaria, Fraxinus excelsior, Gaultheria procumbens, and Populus tremula

\begin{tabular}{|c|c|c|c|}
\hline Mother tinctures & $\begin{array}{c}\text { DPPH } \\
(\mathbf{C C R} \%)\end{array}$ & $\begin{array}{c}\text { ORAC } \\
(\boldsymbol{\mu m o l i ~ t r o l o x} / \mathbf{g})\end{array}$ & $\begin{array}{c}\text { Polyphenols content } \\
(\mathbf{g} \text { GAE/mL) }\end{array}$ \\
\hline Filipendula ulmaria & $82.68 \pm 6.3$ & $5017.2 \pm 6.5$ & $3.72 \pm 5.2$ \\
\hline Fraxinus excelsior & $85 \pm 7.4$ & $1306.55 \pm 7.2$ & $3.40 \pm 5.6$ \\
\hline Gaultheria procumbens & $87.69 \pm 4.5$ & $1200 \pm 8.7$ & $3.58 \pm 4.9$ \\
\hline Populus tremula & $82.28 \pm 5.2$ & $2204.5 \pm 2.5$ & $3.65 \pm 2.3$ \\
\hline
\end{tabular}

Each value is the average of three measurements \pm standard deviation (SD) 
FARMACIA, 2019, Vol. 67, 2

As it can be seen in Table I, the polyphenol content as well as the scavenging capacity (DPPH) of these four mother tinctures are almost the same. DPPH and ORAC assay are based on free radical scavenging but ORAC assay uses aqueous solutions and not ethanolic ones. Due to this, probably DPPH describes all types of antioxidants, whereas ORAC assay measures the more hydrophylic molecules [3]. According to ORAC assay, Populus tremula, Fraxinus excelsior and Gaultheria procumbens mother tinctures have an antioxidant capacity of
2.28, 3.84 and 4.18 folds lower than Filipendula ulmaria.

In vitro cytotoxicity studies

The results obtained from the MTT test (Figure 1) revealed values of cell viability close to those of control for the tinctures obtained from Gaultheria procumbens, Filipendula ulmaria and Fraxinus excelsior irrespectively of the incubation time. In the case of Populus tremula tincture, a slight decrease of cell viability, by $15 \%$ and $25 \%$ of control, was observed after 24 and 48 hours, respectively.

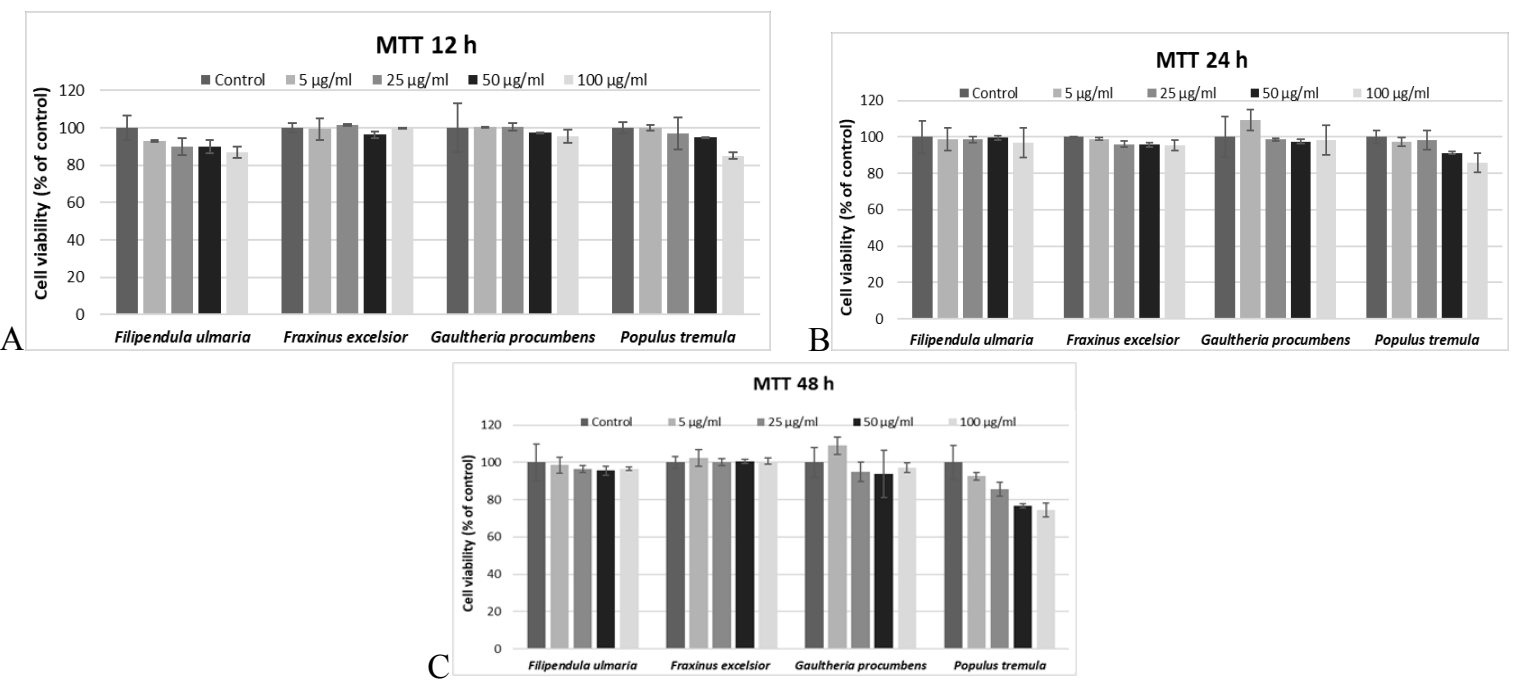

Figure 1.

Cell viability assessed by the MTT assay after incubation of the intestinal cells for $12 \mathrm{~h}(\mathrm{~A}), 24 \mathrm{~h}(\mathrm{~B})$ and $48 \mathrm{~h}$ (C) with different concentrations $(5,25,50$ and $100 \mu \mathrm{g} / \mathrm{mL})$ of the selected tinctures

As it can be seen in Figure 2, the treatment of Caco-2 cells with the four plant extracts at doses of $25 \mu \mathrm{g} / \mathrm{mL}$ and $100 \mu \mathrm{g} / \mathrm{mL}$ had no effect on lipid peroxidation. But in the case of oxidative stress induced by 250 $\mu \mathrm{M}$ hydrogen peroxide, followed by treatment with these extracts, the level of MDA increased in a time dependent manner.
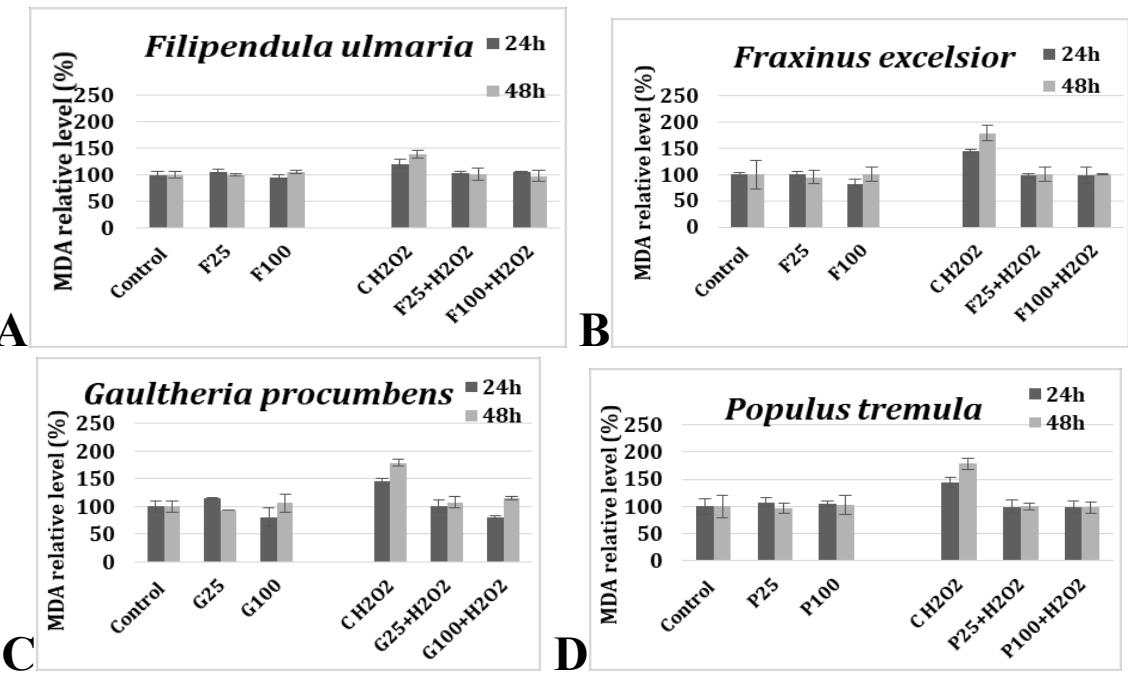

Figure 2.

MDA level in Caco-2 cells after incubation for 24 and 48 hours with hydrogen peroxide and different concentrations $(25$ and $100 \mu \mathrm{g} / \mathrm{mL})$ of the selected tinctures 
FARMACIA, 2019, Vol. 67, 2

But after an incubation of one hour with $250 \mu \mathrm{M}$ hydrogen peroxide, the adding of all four mother tinctures decreased the level of lipid peroxidation irrespectively of time and concentration. The induction of oxidative stress and inflammation was achieved in our study by the addition of hydrogen peroxide in the cell culture media. Other models of inflammation study involve the administration of turpentine oil or dextran sulphate sodium to murine organisms [2, 13]. The antioxidant and antiinflammatory effects of the four plant extracts have been highlighted in our work by various methods based on the ability to neutralize free radicals and reduce lipid peroxidation, probably due to their higher levels of total phenolic compounds. In comparison, Proestos et al. [16] reported that very good antioxidant activity of meadowsweet flowers (DPPH and ferric reducing antioxidant power methods).

Results comparable to our study were reported for other ethanolic plant extracts, such as the therapeutic effect of berberine extract in ulcerative colitis experimentally induced in mice by maintaining the stability of the colon mucosa mechanical barrier [13], and the antioxidant and anti-inflammatory activity of Mahonia aquifolium leaf and bark extracts [2]. The study of the hydroalcoholic effect of Crocus sativus L. extract on colon cells showed no significant changes in cell viability [12].

Lipid oxidation can be generated in inflammatory bowel disease [1], and represents a marker of oxidative stress. Considering the good antioxidant activity of Filipendula ulmaria through the reduction of lipid peroxidation in colon cells, we can suggest its further use for in vivo inflammation models.

\section{Conclusions}

Our results revealed that the most potent plant extract in the treatment of intestinal inflammatory pathologies is Filipendula ulmaria mother tincture, probably due to the high level of polyphenols. Therefore, these findings provide valuable information in order to introduce these mother tinctures on the market of homeopathic products.

\section{Acknowledgement}

This work was financially supported from Project no. 12BG/PN-III-P2-2.1-BG-2016-0100, 2016-2018, granted by the Executive Agency for Higher Education, Research, Development and Innovation Funding (UEFISCDI).

\section{References}

1. Alzoghaibi MA, Al Mofleh IA, Al-Jebreen AM, Lipid peroxides in patients with inflammatory bowel disease. Saudi J Gastroenterol., 2007; 13(4): 187-190.

2. Andreicut AD, Parvu AE, Mot AC, Parvu M, Fischer-Fodor E, Feldrihan V, Catoi AF, Cecan M, Irimie A, Anti-inflammatory and antioxidant effects of Mahonia aquifolium leaves and bark extracts. Farmacia, 2018; 66(1): 49-58.

3. Benedec D, Oniga I, Muresan B, Mot AC, Damian G, Nistor A, Silaghi-Dumitrescu R, Hanganu D, Duma M, Vlase L, Contrast between water- and ethanol-based antioxidant assays: aspen (Populus tremula) and black poplar (Populus nigra) extracts as a case study. J Food Quality, 2014; 59: 45274536.

4. Bradford MM, A rapid and sensitive method for the quantitation of microgram quantities of protein utilizing the principle of proteindye binding. Anal Biochem., 1976; 72: 248-254.

5. Burits M, Bucar F, Antioxidant activity of Nigella sativa essential oil. Phyto Res., 2000; 14: 323-328.

6. Dai J, Russell JM, Plant phenolics: Extraction, analysis and their antioxidant and anticancer properties. Molecules, 2010; 15: 7313-7352.

7. Dávalos A, Gomez-Cordovés Cé, Bartolomé B, Extending Applicability of the Oxygen Radical Absorbance Capacity (ORAC-Fluorescein) Assay. J Agric Food Chem., 2004; 52: 48-54.

8. Del Rio D, Pellegrini N, Colombi B, Bianchi M, Serafini M, Torta F, Tegoni M, Musci M, Brighenti F, Rapid Fluorimetric method to detect total plasma malondialdehyde with mild derivatization conditions. Clin Chem., 2003; 49: 690-692.

9. Kaplan G, The global burden of IBD: from 2015 to 2025. Nat Rev Gastroenterol \& Hepatol., 2015; 12 : 720-727.

10. Kasote DM, Katyare SS, Hegde MV, Bae H, Significance of Antioxidant Potential of Plants and its Relevance to Therapeutic Applications. Int $J$ of Biol Sci., 2015; 11(8): 982-991.

11. Katanic J, Boroja T, Stankovic N, Mihailovic V, Mladenovic M, Kreft S, Vrvic MM, Bioactivity, stability and phenolic characterization of Filipendula ulmaria (L.) Maxim. Food Funct., 2015; 12: 1-34.

12. Lautenschläger $\mathrm{M}$, Sendker J, Hüwel $\mathrm{S}$, Galla HJ, Brandt S, Düfer M, Riehemann K, Hensel A, Intestinal formation of trans-crocetin from saffron extract (Crocus sativus L.) and in vitro permeation through intestinal and blood brain barrier. Phytomedecine, 2015; 22: 36-44.

13. Li S, Shen Y, The therapeutic effects of berberine extract on ulcerative colitis in mice. Farmacia, 2018; 66(3): 442-451.

14. Michel P, Dobrowolska A, Kicel A, Owczarek A, Bazylko A, Granica S, Piwowarski JP, Olszewska MA, Polyphenolic profile, antioxidant and antiinflammatory activity of eastern teaberry (Gaultheria procumbens L.) leaf extracts. Molecules, 2014; 19(12): 20498-20520.

15. Mosmann J, Rapid colorimetric assay for cellular growth and survival. J Immunol Methods, 1983; 65: 53-63.

16. Proestos C, Zoumpoulakis $\mathrm{P}$, and Sinanoglou VJ, Determination of plant bioactive compounds. 
Antioxidant capacity and antimicrobial screening. Focusing on Modern Food Industry (FMFI), 2013; 2 (1): 26-35.

17. Scarborough P, Allender S, Rayner M, Goldacre M, Validation of model-based estimates (synthetic estimates) of the prevalence of risk factors for coronary heart disease for wards in England. Health Place, 2009; 1: 54-60.

18. Singleton VL, Orthofer R, Lamuela-Raventos RM, Analysis of total phenols and other oxidation substrates and antioxidants by means of FolinCiocalteu reagent. Methods in Enzymol., 1999; 299: 152-178.

19. Skuladottir H, Tjoenneland A, Overvad K, Stripp $\mathrm{C}$, Olsen $\mathrm{JH}$, Does high intake of fruit and vegetables improve lung cancer survival? Lung Cancer, 2006; 3: 267-273.

20. Thomas PA, Biological flora of the British Isles: Fraxinus excelsior. Journal of Ecology, 2016; 104: 1158-1209. 